\title{
THE MERGER OF FATA: BREAKING THE CLUTCHES OF BRITISH COLONIAL FRONTIER CRIMES REGULATIONS (FCR)
}

\section{Alamgeer Khan ${ }^{1 *}$, Intikhab Alam ${ }^{2}$, Mussawar Shah ${ }^{3}$, Asad Ullah $^{4}$, Malik Muhammad Shafi ${ }^{5}$}

${ }^{1 *} \mathrm{Ph}$.D. Scholar \& Lecturer Rural Sociology, The University of Agriculture Peshawar Pakistan; ${ }^{2}$ Lecturer Rural Sociology, The University of Agriculture Peshawar Pakistan; ${ }^{3}$ Chairman/Professor, Department of Rural Sociology, The University of Agriculture Peshawar Pakistan; ${ }^{4}$ Assistant Professor Rural Sociology, The University of Agriculture Peshawar Pakistan; ${ }^{5}$ Assistant Professor Rural Development, The University of Agriculture Peshawar Pakistan. Email: ${ }^{1 *}$ alamgeer@aup.edu.pk, ${ }^{2}$ intikhab@ aup.edu.pk, ${ }^{3}$ rural_sociologist@ hotmail.com, ${ }^{4}$ asadpsh@aup.edu.pk, 5 drmms@aup.edu.pk

\section{Article History: Received on $10^{\text {th }}$ February 2021, Revised on $5^{\text {th }}$ March 2021, Published on $10^{\text {th }}$ March 2021}

\begin{abstract}
Purpose of the study: The present study aimed to find the association between frontier crime regulations (FCR) abolishment (independent variable) in the context of the merger of FATA with Khyber Pakhtunkhwa (dependent variable).

Methodology: The study follows a crossectional research design. Primary data were collected from 384 randomly selected respondents of the two newly merged districts, Khyber and Kurram of Khyber Pakhtunkhwa province. The association and strength of the relationship were obtained by the application of Chi-Square $(\chi 2)$ and Kandel Tau $b\left(T^{b}\right)$ test statistics.
\end{abstract}

Main Findings: Based on the obtained statistics, the FCR law was against fundamental rights, favoring the local elites, a hurdle to development, a source of corruption, outdated and inefficient in counter militancy, unpopular, and the tribals ready to welcome the modern governance system. The background variables gender and age yielded spurious relationships. At the same time, socio-economic status resulted in a non-spurious relationship between the variables above.

Applications of this study: The research results can be applied to such studies that focus on the indigenous culture, governance, and fundamental human rights.

Novelty/Originality of this study: This study's unique feature is that it is the first-ever attempt to investigate such kinds of topics in Pakistan's tribal regions. Besides, it also provides an outlook of the inhuman and unjustified state-sponsored FCR.

Keywords: FCR, Merger, Fundamental Rights, Violation, Development.

\section{INTRODUCTION}

The Federally Administered Tribal Areas (FATA) was a semi-autonomous tribal region in northwestern Pakistan, comprised of seven agencies and six frontier regions (Saddique et al., 2018; FATA Disaster Management Authority, 2018). The covered area is $27,220 \mathrm{~km} 2$ sheltered five million, with a large 7.8 average household size and 97 percent of the inhabitant living in rural areas (Saddique et al., 2018; Pakistan Bureau of Statistics, 2017). The merged FATA borders Pakistan's provinces of Khyber Pakhtunkhwa and Baluchistan to the east and south, and Afghanistan's provinces of Kunar, Nangarhar, Paktika, Khost, and Paktika to the west and north (Office for the Coordination of Humanitarian Affairs OCHA, 2018). Since the 1850s, the region unwaveringly ruled through a unique, separate, and notorious British colonial governance model, the Frontier Crimes Regulations (FCR) ( Yousaf, 2019; Amnesty International, 2018). The FCR introduced by a British viceroy aimed to control and subjugate Pashtuns (Yousaf \& FurrukhZad, 2020). Lord Curzon crafted FCR to resemble Pashtunwali (the local laws) with which the tribal governed themselves (Shaw, 2012). After independence, FCR was implemented on the tribals via Article 247 of the Pakistan constitution (Yousafzai, 2018; Ullah, 2013). The implementation of FCR gave the opportunity and right as well to the federal government to run these territories by Political Agents (Shaw et al., 2012; Amnesty International, 2010; Mahmud, 2010; Tanguay-Renaud, 2009; Spains, 1979)

Under the FCR, the governor of Khyber Pakhtunkhwa appointed a Political Agent, a senior bureaucrat who used to be the chief commissioner/ administrator in the agency and served as a bridge between the locals and the president (Ali, 2018; Islam et al., 2017). The Political Agent, being the administrator of the agency, assisted by Assistant Political Agents (APA), Tehsildars, Naib Tehsildars, local Khassadars/levies (police), and local elders (Maliks) (Ullah, 2015; Latif et al., 2012). Political Agent was the most influential person who used to lead all line departments in the agency and was involved in every aspect of the local people's lives (Khattak, 2017; Shaw et al., 2012). The FCR gave additional power to the PA. Besides the head of political administration, the PA had the authority of revenue collection, leading all development activities, judging civil and criminal cases, directing the planning \& coordinating activities, and acting as district returning officer (DRO) during elections (Ullah, 2014; Democracy Reporting International, 2013). The PA had many essential responsibilities, but the most important was maintaining a low crime ratio and sustainable peace in his agency (Mahsud et al., 2016). Apart from his subordinate civilian officers, the PA was also assisted by local elders 
(Maliks) paid elderly mediators (Khan, 2017). The status of Maliks was at the discretion of PA; he could be removed at any time without any reason. In case of any dispute or threat to peace in his territory, the PA had powers to initiate cases himself. Also, he could constitute indigenous conflict resolution body Jirga (of his wish and well) to solve the matter according to the tribal norms. He presided over trials and punished the accused, determined by the Jirga. The PA also had the power to reject the Jirga's decision, refer the case or dispute back to the Jirga, or hand it over to another Jirga (Yousaf et al., 2018).

Under clauses 21-24 of FCR, the Political Agents could punish an entire tribe for acting in an offensive, subversive or hostile way against the State (Khan et al., 2012). The Political Agents held power to punished the entire tribe if a crime was committed on the territory under his control. Such punishments included fines, arrests, seizure of both moveable and immoveable property, and blocking their access to Pakistan's settled areas (Tahir, 2015). The punishments were also applicable to the members or tribes not bringing the culprits to the PA's court, helping apprehended criminals, or suppressing the evidence of a crime committed on their territory. The only segment of society that excluded from such punishments (collective punishment) were women, aged men (over 65 years), and children (under 16 years) (Government of Pakistan, 2011). PA's power was not restricted to tribal borders, but he could seize the business or property of tribal people in Pakistan's settled districts on the analogy of FCR section 21 (Shah, 2006). This concept of collective punishment violates international law and is termed a war crime under the 1949 Geneva Conventions (Fabricant, 2010). The State assigned immense powers to the political agents to rule FATA on the yardstick of force rather than democracy. This has brought colossal criticism from civil rights activities and humanitarians. The FCR had explicitly denied the fundamental human rights to tribal people, such as the legal right of representation (Akins, 2018), the appeal of detention (Ullah, 2015), and the right of provision of evidence in their defense (Hopkins, 2015). These laws were inhumane (U1lah, 2015), degrading (Fair \& Jones, 2009), draconian, oppressive, and against human rights ( $\underline{\mathrm{Ahmad}}$, 2007).

The most alarming fact was that PA's decisions could not be challenged in any court of law. The PA as a judge in tribal was equipped with unlimited powers such as forced displacement of individual even of groups, destruction of houses and buildings of the accused, custody of individuals, collective punishment of a whole tribe for the crime of its single members, imprisonment of children (before 2011 amendments) and even the execution of tribal people (Shinwari, 2012). The Political Agents' funds were inaudible, which leads to bad governance and corruption (Wilson et al., 2019). From top to bottom, FATA officials' corrupt mindset was enjoying the power. The absence of direct interference of anticorruption departments, like FIA (Federal Investigation Agency), NAB (National Accountability Bureau), etc., provided freehand to corrupt officials who looted the region mercilessly (Ali, 2014).

The FCR also lacked a trained police system and miserably failed to control the militancy. After 9/11, the tribal areas became a shelter home for the hundreds of fled terrorists from Afghanistan related to al-Qaeda. The FCR failed to protect the region from militancy and Islamic radicalization, and the Pakistan army has to intervene to control the law and order situation in FATA (Crawford, 2016). The draconian law was considered the mother of all problems that deprived the tribals of legal and political rights and pushed the region into the dark ages (DAWN, 2012). The majority 74 percent of tribal people was the victim of multidimensional poverty (United Nations Development Programme (UNDP, 2016) with only 33 percent literacy rate (Office for the Coordination of Humanitarian Affairs OCHA, 2018) and inadequate employment opportunities (Rubab, 2014). The health condition is also in miserable condition having only one bed for 2179 patients and only 7,670 doctors serving five million tribal people. The child health care statistics are more alarming as 72 percent of babies are born in unhygienic conditions in unprofessional hands (Nazia, 2018). The separate system has isolated the region from the country mainstream, and the area lacked health facilities (Das et al., 2020), electricity (Rafique et al., 2017), proper infrastructure (Shah et al., 2020), irrigation facilities, and quality education institutions (Shakeel, 2019; Hussain et al., 2016; Khan et al., 2012). The loose writ of the State has pushed the region further in poverty, unemployment, socio-economic deprivation, drug trafficking, smuggling, corruption, weapon trade, black markets, terrorism, extremism, Islamic radicalization and turned a threat not only on the national level but on the international level as well (Ullah \& Hayat, 2017).

Thus, in 2015 the policymakers tasked a committee for appropriate recommendations to bring the tribal areas into the national mainstream to extend the writ of the State; prevent pro militancy sentiments; protect fundamental human rights; bring sustainable peace and development (Yusufzai, 2018). The committee held a series of meetings with the locals, including Maliks, civil society, journalists, and FATA youth. In the initial stages, the committee recommended the need to accelerate development, restore fundamental rights, and demolish the buffer status of FATA. However, they brought four practical possibilities. These were (a) separate provinces for FATA (b) FATA merger with Khyber Pakhtunkhwa (c) making FATA an autonomous state like Gilgit Baltistan, and (d) administrative reform in the current status-quo. The committee also stressed the merger of FATA with Khyber Pakhtunkhwa as the most appropriate, realistic, and feasible option (Associated Press of Pakistan (APP), 2016; Aziz, 2017). However, the official merger of FATA in May 2018 was not a consistent choice over the political spectrum. The Jamiat Ulema-i-Islam Fazal (JUI-F), along with Pakhtunkhwa Mili Awami Party (PKMAP), the political allies of the then incumbent PML-N (Pakistan Muslim League Nawaz), opposed the bill. According to both parties, the merger of FATA with Khyber Pakhtunkhwa would push the region into a new era of darkness and will abolish tribal culture. JUI-F opposed the merger process and criticized the government for not including tribal people in the decision-making process ( 
into two extremes, where some celebrated the merger while others protested. This paper aimed to investigate the perception of tribal people regarding the old governance system FCR and the merger of FATA with Khyber Pakhtunkhwa.

\section{Objectives of the study}

The central objectives of this paper are delineated as:

1. To assess the perception of tribal people about FCR abolishment in the context of the merger of FATA with Khyber Pakhtunkhwa.

2. To determine age, gender, and socio-economic status variations in FCR abolishment among the tribal people.

3. To advise policy recommendations based on study findings.

\section{METHODOLOGY}

The present investigation based on primary data was carried out in two newly merged districts, Khyber and Kurram, to determine the perception of tribal people regarding FCR abolishment as an outcome of the merger of erstwhile FATA with the Khyber Pakhtunkhwa province. The cross-sectional research design was adopted based on the study's horizon (Babbie, 2013; Kumar, 2011). According to (Pakistan Bureau of Statistics, 2017), district Khyber comprises 111558, and district Kurram had 67244 households. A total of 384 samples were withdrawn on the analogy devised by (Sekaran, 2016). All the tribal people above eighteen years belonging from the mentioned districts were the study's potential respondents. However, while keeping in view the cultural sensitivity of the tribal regions, the women were interviewed by two well-trained, paid female enumerators. Moreover, the proportional allocation method was further applied to determine the sample size from each of the selected tehsils. Furthermore, a simple random sampling technique was applied to pick the samples from each of the selected tehsils; for more details, see below table 1 .

\section{Proportional Allocation Method Formula}

$$
n_{h}=\frac{N_{h}}{N} n
$$

$\mathrm{nh}=$ Proportion of sample allocated to hth strata

$\mathrm{Nh}=$ Population of hth stratum

$\mathrm{n}=$ Total sample size

$\mathrm{N}=$ Total Population

\section{(Chaudhry \& Kamal, 2011)}

Table 1: Tehsil Wise Breakup of Sampled Respondents

\begin{tabular}{lll}
\hline Khyber District & Households & Sample size \\
\hline Bara Tehsil & 51869 & 111 \\
\hline Jamrud Tehsil & 26205 & 56 \\
\hline Landi Kotal Tehsil & 29472 & 63 \\
\hline Mula Ghori Tehsil & 4012 & 9 \\
\hline Total Population & 111558 & 239 \\
\hline Kurram District & & \\
\hline Upper Kurram Tehsil & 25924 & 56 \\
\hline Lower Kurram Tehsil & 14030 & 30 \\
\hline Central Kurram F.R & 27290 & 59 \\
\hline Total Population & 67,244 & 145 \\
\hline Grand Total (Kurram + Khyber) & 178802 & 384 \\
\hline
\end{tabular}

Source: Census Report 2017

\section{Conceptual framework}

The conceptual framework was designed with the dependent variable (Perception of tribal people about the merger of FATA with Khyber Pakhtunkhwa) gender, age, and socio-economic status as background variables and independent variable (Frontier Crime Regulations abolishment) (Table 2).

Table 2: Conceptual framework

\begin{tabular}{lll}
\hline Background Variables & Independent variables & Dependent Variable \\
\hline & Frontier Crimes Regulations (FCR) Abolishment & Perception of the tribal people \\
\hline
\end{tabular}




\section{Measurement of Variable}

For measurement of the FATA merger, eight items were included in the term of the merger acceptability, its role in improving living standards, bringing new avenues, uplifting the underprivileged social class, reassuring women's development participation, political stabilization, discouragement of anti-state elements, dependency on financial resources and bringing administrative chaos in the tribal society. Similarly, the measurement of independent variable FCR abolishment has included ten items, i.e., FCR as cruel, unpopular, in contradiction of fundamental rights, and outdated law. Moreover, a developmental hurdle, source of corruption, benefiting tribal elites, the merger as its replacement, and tribals' inclination towards new governance.

\section{Indexation}

The independent and dependent variables' association at the bivariate analysis level was obtained by cross-tabulating the dependent variable with the independent variable. Moreover, at multivariate level analysis, the independent variable showing Cronbach's alpha coefficient value of more than 0.7 was indexed and cross-tabulated with the dependent variable to determine that variations in FATA merger caused exclusively by FCR abolishment or affected by control variables too.

\section{Methods of Data Analysis}

After, data collection SPSS version 24 was run to obtain univariate, bivariate, and multivariate analysis levels. The univariate investigation included frequency distribution and percentages of the sampled respondents' responses. Also, bivariate analysis was performed to obtain the association between the dependent and independents variables. Moreover, a multivariate analysis was further run to obtain the results based on exploring the spurious and nonspurious relationships between the independent and dependent variables by controlling the background variables age, gender, and socio-economic status. Chi-square and Fisher Exact tests were used to measure the association on both bi and multivariate levels analysis. The association's direction and strength were obtained by applying the Kendal Tau $b$ and Chi-squared test statistics. The chi-squared test introduced by Karl Parson and represented by the symbol $\chi 2$ are generally used to obtain association between dependent and independent variables and summaries of how close the expected frequencies fall to the observed frequencies (Rayat, 2018).

\section{RESULTS/FINDINGS/DISCUSSION/ANALYSIS}

\section{Univariate Data Analysis}

\section{Perception about the Merger of FATA with Khyber Pakhtunkhwa}

Seeking the perception of tribal people about the merger of FATA the table 3 depicted that majority $63.8 \%, 60.9 \%$, $59.4 \%, 59.1 \%$, and $56.1 \%$ of the tribal people liked the merger process, as they thought that it would bring improvement in the living standard, new avenues, uplift the low segments, and incorporate tribal women in development endeavors respectively. Moreover, $69 \%$ and $60.4 \%$ of the tribal people believed that the merger is essential for political stability and demoralized anti-state elements. However, the majority $80.7 \%$ of the tribals, also stated that the merger is highly dependent on the allocation of funds, followed by $56.5 \%$ of respondents who reported that the process had brought administrative chaos.

Table 3: Perception about the Merger of FATA with Khyber Pakhtunkhwa

\begin{tabular}{llll}
\hline Statements & Agreed & Disagreed & Not sure \\
\hline You personally like the FATA merger into Khyber Pakhtunkhwa & $245(63.8 \%)$ & $\begin{array}{l}97 \\
(25.3 \%)\end{array}$ & $\begin{array}{l}42 \\
(10.9 \%)\end{array}$ \\
\hline The merger will improve the living standard of the FATA inhabitants & 234 & 86 & 64 \\
& $(60.9 \%)$ & $(22.4 \%)$ & $(16.7 \%)$ \\
\hline $\begin{array}{l}\text { Merger will bring new avenues of life (employment opportunities/mega } \\
\text { projects) for tribal people }\end{array}$ & $\begin{array}{l}228 \\
(59.4 \%)\end{array}$ & $\begin{array}{l}76 \\
(19.8 \%)\end{array}$ & $\begin{array}{l}80 \\
(20.8 \%)\end{array}$ \\
\hline Merger is more beneficial for poor segments of tribal population & 227 & 84 & 73 \\
& $(59.1 \%)$ & $(21.9 \%)$ & $(19.0 \%)$ \\
\hline The merger will increase women participation in development endeavors & 217 & 92 & 75 \\
& $(56.5 \%)$ & $(24.0 \%)$ & $(19.5 \%)$ \\
\hline The merger is essential for political normalization (stability) in the & 265 & 63 & 56 \\
erstwhile FATA. & $(69.0 \%)$ & $(16.4 \%)$ & $(14.6 \%)$ \\
\hline Merger has demoralize anti-sate elements & 232 & 70 & 82 \\
& $(60.4 \%)$ & $(18.2 \%)$ & $(21.4 \%)$ \\
\hline Successful merger is highly dependent on provision of funds & 310 & $33(8.6 \%)$ & 41 \\
\hline
\end{tabular}




\begin{tabular}{llll}
\hline & $(80.7 \%)$ & & $(10.7 \%)$ \\
\hline Merger has brought administrative chaos & 217 & 88 & 79 \\
& $(56.5 \%)$ & $(22.9 \%)$ & $(20.6 \%)$ \\
\hline
\end{tabular}

Source: Survey, 2019-2020

\section{Frontier Crimes Regulations (FCR) Abolishment}

Table 4 on the perceptions of tribal people about FCR abolishment disclosed that the majority $66.4 \%$ and 66,7 the respondents were well aware of the draconian law (FCR) dealing the tribal with a carrot \& stick approach considered FCR as the main hurdle in developing erstwhile FATA. Furthermore, the majority 66.7, 59.9\%, $69.5 \%$, $69 \%$, and 75.26 respondents declared FCR a source of corruption, an outdated law to counter-insurgency, FCR abolishment as their main demand, the merger had replaced the cruel FCR and its inhuman clause of collective responsibility respectively. Also, the majority of $60.7 \%$ of the respondents reported that abolishing FCR has decreased the roles and benefits of Maliks. Moreover, another majority $60 \%$ and $64.1 \%$ of the respondents, considered the merger the best solution to replace FCR and welcomed the governance system, respectively.

Table 4: Sampled Respondents Perception Regarding Frontier Crimes Regulations (FCR) Abolishment

\begin{tabular}{|c|c|c|c|}
\hline Statements & Agreed & Disagreed & Not Sure \\
\hline $\begin{array}{l}\text { FCR denied basic and } \\
\text { constitutional rights }\end{array}$ & $255(66.4 \%)$ & $52(13.8 \%)$ & $43(19.8 \%)$ \\
\hline $\begin{array}{l}\text { FCR was the main hurdle in } \\
\text { the development of FATA }\end{array}$ & $256(66.7 \%)$ & $91(23.7 \%)$ & $37(9.6 \%)$ \\
\hline $\begin{array}{l}\text { FCR was a source of } \\
\text { corruption in FATA }\end{array}$ & $256(66.7 \%)$ & $66(17.2 \%)$ & $62(16.1 \%)$ \\
\hline $\begin{array}{l}\text { FCR was outdated law to } \\
\text { counter militancy in FATA }\end{array}$ & $230(59.9 \%)$ & $88(22.9 \%)$ & $66(17.2 \%)$ \\
\hline $\begin{array}{l}\text { Abolishment of FCR was the } \\
\text { main demand of the people }\end{array}$ & $267(69.5 \%)$ & $72(18.8 \%)$ & $45(11.7 \%)$ \\
\hline $\begin{array}{l}\text { Merger has replaced FCR } \\
\text { cruel approach of dealing } \\
\text { tribal by force }\end{array}$ & $265(69.0 \%)$ & $63(16.4 \%)$ & $56(14.6 \%)$ \\
\hline $\begin{array}{l}\text { Merger has abolished the cruel } \\
\text { FCR clause of collective } \\
\text { responsibility }\end{array}$ & $289(75.3 \%)$ & $51(13.3 \%)$ & $44(11.5 \%)$ \\
\hline $\begin{array}{l}\text { After the abolishment of FCR, } \\
\text { the roles and benefits of } \\
\text { Maliks (Longi holders) has } \\
\text { decreased }\end{array}$ & $233(60.7 \%)$ & $91(23.7 \%)$ & $60(15.6 \%)$ \\
\hline $\begin{array}{l}\text { Merger is the best solution for } \\
\text { getting rid of FCR }\end{array}$ & $233(60.7 \%)$ & $100(26.0 \%)$ & $51(13.3 \%)$ \\
\hline $\begin{array}{l}\text { Tribal people will welcome } \\
\text { new governance system }\end{array}$ & $246(64.1 \%)$ & $64(16.7 \%)$ & $74(19.3 \%)$ \\
\hline
\end{tabular}

Source: Survey, 2019-2020

\section{Bivariate Analysis}

\section{Association Between Frontier Crimes Regulations Abolishment and Perception of the Tribal People About the Merger of FATA with Khyber Pakhtunkhwa}

Table 5 shows a significant association $(\mathrm{P}=0.001)$ with positive $\left(\mathrm{T}^{\mathrm{b}}=0.192\right)$ between the statement $\mathrm{FCR}$ denied fundamental and constitutional rights and the dependent variable perception of the tribal people about the merger of FATA with Khyber Pakhtunkhwa. Article 1 of the 1973 constitution declared FATA a part of Pakistan, but articles 54, 59, 255 put it under the president's direct control. Being an unconstitutional law, FCR was removed from some parts of Baluchistan and Khyber Pakhtunkhwa. However, FATA people were subjected to this draconian law till 2018. The FCR contradicted the constitution of 1973 and was a complete violation of universal human rights.

The study further explored the positive and highly significant association between the statements FCR was the main hurdle in developing FATA $\left(\mathrm{T}^{\mathrm{b}}=0.303\right.$ and $\left.\mathrm{P}=0.000\right)$, source of corruption $\left(\mathrm{T}^{\mathrm{b}}=0.281\right.$ and $\left.\mathrm{P}=0.000\right)$, outdated law to counter-insurgency $\left(\mathrm{T}^{\mathrm{b}}=0.281 \& \mathrm{P}=0.000\right)$ and the perception of the tribal people about the merger of FATA with Khyber Pakhtunkhwa. Apart from depriving the tribals of human and fundamental rights, FCR was a big hurdle in the development. The political agent for being a one-man show did not encourage participatory development in the areas, and hence the area remained far behind the adjacent settled areas. Poverty, illiteracy, and unemployment can be directly linked to the old and dysfunctional governance model. (Akins, 2017; Javaid, Haq, \& Akram, 2016) also found that the 
weak governance system is a significant problem in FATA. Without any check and balance, the political agent spent developmental and non-development funds. The political agent issued goods permits in the name of agency welfare funds. However, even the traders have no idea that the money is going to the government treachery or in political administration pockets.

Hence, the FCR system was responsible for the spread of corruption. The only people with power and privileges were Maliks and political administration, who passed little benefits to the broader population. FCR also lacked a trained police system and miserably failed to control the militancy. Hence, it can be concluded that FCR was violating locals' rights, and on the other side, it failed to protect them from militancy and Islamic radicalization. (Walsh \& Piazza, 2010)) also reported that countries that respect citizens' physical integrity (avoiding torture and cruel handling) tend to experience less terrorist violence. Moreover, effective judiciary and democracy are negatively associated with terrorism (Walsh \& Piazza, 2010), which was missing in the erstwhile FATA.

On the other hand, (Lutz \& Lutz, 2010) have given a more precise picture directly related to the erstwhile FATA's situation. They stated that states with severe political, social, economic, and ethnic fragmentation and inequalities are more vulnerable to terrorism. It can be concluded that FCR was a weak system with no police, judiciary, and democracy that not only resulted in massive corruption but also failed miserably in countering insurgency.

Also, positive and highly significant associations were obtained between the statements abolishment of FCR was the main demand of the tribal people $\left(\mathrm{T}^{\mathrm{b}}=0.356 \& \mathrm{P}=0.000\right)$, the merger has replaced FCR cruel approach of dealing with the tribals by force $\left(\mathrm{T}^{\mathrm{b}}=0.471 \& \mathrm{P}=.000\right)$, has abolished FCR cruel clause of collective or territorial responsibility $\left(\mathrm{T}^{\mathrm{b}}=\right.$ $0.456 \& \mathrm{P}=.000$ ) and perception of the tribal people about the merger of FATA with Khyber Pakhtunkhwa. The FCR denied the tribals' freedom of expression and fair trial; moreover, with time, the tribals started protesting against FCR on almost every platform they came by. Being the citizens of Pakistan, they demanded equal rights and presented a straightforward plea that if FCR is better law, why the State does not extend it to the rest of the country. (Hussain, 2005; Khan, 2017; Shakirullah, 2005; Shinwari, 2005; The Express Tribune, 2015; Times, 2017) also reported that most FATA tribesmen want FCR abolishment without any delay. Also, (Khan, 2018) reported that most FATA inhabitants are peace and democracy lovers. They want to evolve democratically and demand equal human rights, social and political participation, reforms, and transparency. The merger has swapped cruel and severe FCR, and the tribals are now enjoying it.

Moreover, positive and highly significant associations were found between the dependent variable and independent variable statement significant decreased roles and privileges of Maliks due to the FCR abolishment $\left(T^{\mathrm{b}}=0.288\right.$ \& $\mathrm{P}=0.000)$, the merger as best option chosen for getting rid of FCR $\left(\mathrm{P}=0.000 \& \mathrm{~T}^{\mathrm{b}}=0.427\right)$, and tribal people ready to welcome the new governance system $\left(\mathrm{T}^{\mathrm{b}}=0.445 \& \mathrm{P}=0.000\right)$. The role of Maliks in Pashtun's society cannot be ignored; in FATA, they held a much firm ground compared to the settled areas. In FATA, the Maliks elected public representatives from FATA through an electoral college of Maliks until the adult franchise's introduction as late as 1997. The Maliki system is hereditary, and most of them are from the upper class. Being mediators between political administration and their tribesmen, Maliks received privileges from the State to maintain peace and suppress crime in their area. After the mainstreaming of FATA, the FCR beneficiaries, Maliks, would lose their perks, power, and privileges (Naseer \& Khalil, 2017). The locals were very optimistic about the merger of FATA with Khyber Pakhtunkhwa. They believed that the merger would bring social, political, judicial, and economic improvement in the erstwhile FATA (Zaman, Mansoor, \& Naz, 2016).

Table 5: Association Between Frontier Crimes Regulations Abolishment and Perception of the Tribal People About the Merger of FATA with Khyber Pakhtunkhwa

\begin{tabular}{lll}
$\begin{array}{l}\text { Frontier Crimes Regulations Abolishment (Independent } \\
\text { Variable) } \\
\text { Statements }\end{array}$ & Dependent Variable & Statistics \\
\hline FCR denied basic and constitutional rights & FATA merger & $\begin{array}{l}\chi^{2}=18.600(0.001) \\
\mathrm{T}^{\mathrm{b}}=0.192\end{array}$ \\
\hline FCR was the main hurdle in the development of FATA & FATA merger & $\begin{array}{l}\chi^{2}=51.499(0.000) \\
\mathrm{T}^{\mathrm{b}}=0.303\end{array}$ \\
\hline FCR was a source of corruption in FATA & FATA merger & $\begin{array}{l}\chi^{2}=43.299(0.000) \\
\mathrm{T}^{\mathrm{b}}=0.281\end{array}$ \\
\hline FCR was outdated law to counter militancy in FATA & FATA merger & $\begin{array}{l}\chi^{2}=53.010(0.000) \\
\mathrm{T}^{\mathrm{b}}=0.338\end{array}$ \\
& & $\begin{array}{l}\chi^{2}=57.934(0.000) \\
\mathrm{T}^{\mathrm{b}}=0.356\end{array}$ \\
\hline Abolishment of FCR was the main demand of the people & FATA merger & $\begin{array}{l}\chi^{2}=107.911(0.000) \\
\mathrm{T}^{\mathrm{b}}=0.471\end{array}$ \\
\hline $\begin{array}{l}\text { The merger has replaced FCR cruel approach of dealingFATA merger } \\
\text { tribal by force }\end{array}$ & & $\begin{array}{l}\chi^{2}=97.505(0.000) \\
\mathrm{T}^{\mathrm{b}}=0.456\end{array}$ \\
\hline Merger has abolished the cruel FCR clause of collectiveFATA merger \\
responsibility
\end{tabular}




\begin{tabular}{|c|c|c|}
\hline $\begin{array}{l}\text { After the abolishment of FCR, the roles and ben } \\
\text { Maliks (Longi holders) has decreased }\end{array}$ & ffFATA merger & $\begin{array}{l}\chi 2=41.091(0.000) \\
\mathrm{T}^{\mathrm{b}}=0.288\end{array}$ \\
\hline The merger is the best solution for getting rid of FCR & FATA merger & $\begin{array}{l}\chi 2=95.080(0.000) \\
\mathrm{T}^{\mathrm{b}}=0.427\end{array}$ \\
\hline Tribal people will welcome new & FATA merger & $\begin{array}{l}\chi^{2}=112.656(0.000) \\
\mathrm{T}^{\mathrm{b}}=0.445\end{array}$ \\
\hline
\end{tabular}

Source: Survey, 2019-2020

\section{Multivariate Analysis}

\section{Association Between Frontier Crime Regulations Abolishment and perception of the Tribal People about the Merger of FATA with Khyber Pakhtunkhwa Controlling Gender, age and socio-economic status of the Respondents}

Table 6: Association Between Frontier Crime Regulations Abolishment and perception of the Tribal People about the Merger of FATA with Khyber Pakhtunkhwa Controlling Gender, age and socio-economic status of the Respondents

\begin{tabular}{|c|c|c|c|c|c|}
\hline Independent Variable & $\begin{array}{l}\text { Dependent } \\
\text { Variable }\end{array}$ & Background Va & able & Statistics & Statistics \\
\hline \multirow{7}{*}{$\begin{array}{l}\text { Frontier Crimes } \\
\text { Regulations Abolishment }\end{array}$} & \multirow{7}{*}{ FATA Merger } & \multirow{2}{*}{ Gender } & Male & $\begin{array}{l}\chi 2=103.348(0.000) \\
\mathrm{T}^{\mathrm{b}}=0.506\end{array}$ & \multirow{7}{*}{$\begin{array}{l}\chi 2= \\
101.882 \\
(0.000) \\
\mathrm{T}^{\mathrm{b}}=0.470\end{array}$} \\
\hline & & & Female & $\begin{array}{l}\chi 2=9.733(0.045) \\
\mathrm{T}^{\mathrm{b}}=0.314\end{array}$ & \\
\hline & & \multirow{3}{*}{ Age } & $\begin{array}{l}\text { Young adults } \\
(18-35)\end{array}$ & $\begin{array}{l}\chi^{2}=72.327 \quad(0.000) \\
T^{b}=0.473\end{array}$ & \\
\hline & & & $\begin{array}{l}\text { Middle-aged } \\
\text { adults } \\
(36-55)\end{array}$ & $\begin{array}{l}\chi 2=32.685 \quad(0.000) \\
\mathrm{T}^{\mathrm{b}}=0.474\end{array}$ & \\
\hline & & & $\begin{array}{l}\text { Older adults } \\
(56 \& \text { above })\end{array}$ & $\begin{array}{l}\chi 2=5.250 \quad(0.072) \\
T^{b}=0.369\end{array}$ & \\
\hline & & \multirow{2}{*}{$\begin{array}{l}\text { Socio-economic } \\
\text { Status }\end{array}$} & $\begin{array}{ll}\text { Low } & \text { Social } \\
\text { Status } & \\
\end{array}$ & $\begin{array}{l}\chi^{2}=54.322 \quad(0.000) \\
T^{b}=0.495\end{array}$ & \\
\hline & & & $\begin{array}{ll}\text { High } & \text { Social } \\
\text { Status } & \\
\end{array}$ & $\begin{array}{l}\chi^{2}=54.300 \quad(0.000) \\
\mathrm{T}^{\mathrm{b}}=0.418\end{array}$ & \\
\hline
\end{tabular}

Source: Survey, 2019-2020

Table 6 depicted a significant high association and positive Kendal $\mathrm{T}^{\mathrm{b}}$ value $\left(\mathrm{P}=0.000 \& \mathrm{~T}^{\mathrm{b}}=0.506\right)$ for the male respondent. They believed that Frontier Crime Regulations abolishment had influence and significant association with the perception of the tribal people about the merger of FATA with Khyber Pakhtunkhwa. In the context of female respondents, the table presented a non-significant association and positive Kendal $\mathrm{T}^{\mathrm{b}}$ value $\left(\mathrm{P}=0.045 \& \mathrm{~T}^{\mathrm{b}}=0.314\right)$. The entire table displayed a highly significant association and positive Kendal $\mathrm{Tb}(\mathrm{P}=0.000 \& \mathrm{~Tb}=0.470)$ between Frontier Crimes Regulations abolishment and perception of the tribal people about the merger of FATA with Khyber Pakhtunkhwa for all background variables. Based on the above-obtained values and comparing these with the aggregate values, the relationship between Frontier Crimes Regulations abolishment and perception of the tribal people about the merger of FATA with Khyber Pakhtunkhwa was spurious in the context of gender. Based on these results, it can be concluded that the tribeswomen who had always been kept illiterate, vulnerable to patriarchal practices, and rigid tribal culture were less concerned about abolishing FCR due to FATA's merger as compared to the dominated tribesmen.

In the context of age, the young adults (18-35 years) group depicted a highly significant and positive association $\left(\mathrm{P}=0.000 \& \mathrm{~T}^{\mathrm{b}}=0.473\right)$ between the variables mentioned above. Similarly, the influence of middle-aged adults (36-55 years) was also found highly significant and positive $\left(\mathrm{P}=0.000 \& \mathrm{~T}^{\mathrm{b}}=0.474\right)$. However, the association between the dependent and independent variables for older adults (55 years \& above) was non-significant and positive $(\mathrm{P}=072 \&$ $\left.\mathrm{T}^{\mathrm{b}}=0.369\right)$. By comparing the values with the aggregate statistics $\left(\mathrm{P}=0.000 \& \mathrm{~T}^{\mathrm{b}}=0.470\right)$, it can be concluded that the relationship between FCR abolishment and perception about the merger of FATA with Khyber Pakhtunkhwa was spurious in the context of age. Furthermore, the values of young adults and middle-aged adults show more influence than older adults. The results portrayed that older adults were less concerned about abolishing FCR due to the FATA merger compared to the other two age groups.

The table further explained the association between Frontier Crimes Regulations abolishment and perception of the tribal people about the merger of FATA with Khyber Pakhtunkhwa controlling the respondents' socio-economic status. The table displayed highly significant and positive association for both low $\left(\mathrm{P}=0.000 \& \mathrm{~T}^{\mathrm{b}}=0.495\right)$ and high social status $\left(\mathrm{P}=0.000 \& \mathrm{~T}^{\mathrm{b}}=0.418\right)$ groups. By comparing the table's Kendal $\mathrm{Tb}$ values, no significant variation was found, resulting 
in non-spuriousness in the relationship. However, the low social group was more influencing the association between the variables above.

\section{CONCLUSION}

Based on study findings, it can be concluded that FCR was significantly unpopular in the erstwhile FATA. The law was harsh, who dealt the tribals with a carrot and stick approach. The law has violated the tribals' constitutional and fundamental rights and miserably failed to protect them against modern-day terrorism, radicalization, and extremism. The weak law favored the tribal elites (bureaucracy and Maliks) and failed to control corruption; consequently, the area was pushed into dark ages regarding political and socio-economic development. The unfavorable prevailing situation forced the inhabitants to support the merger of erstwhile FATA with Khyber Pakhtunkhwa. The merger has released the tribal people from the clutches of inhuman and cruel FCR. The merger is also expected to bring a new era of peace, prosperity, and development in the newly merged region.

\section{RECOMMENDATION}

Due to the low literacy ratio, most of the tribals are unaware of their fundamental human rights. The government and donor agencies need to launch awareness campaigns regarding the new governance model (democracy) and the judiciary's role in protecting fundamental human rights. Also, a mandatory responsibility comes on the concerned sectors to empower the tribals' to protect their due rights and organize them in such a way that they could utilize the new governance system for the uplift of the undeveloped and deprived erstwhile FATA

\section{LIMITATION AND STUDY FORWARD}

This study was limited to FCR abolishment. The authors intend to further study the merger process in the context of political, social, and administrative paradigm changes and their impacts on the indigenous tribal people.

\section{ACKNOWLEDGEMENT}

The study has not received any funding or support. The researchers are grateful to the tribesmen and tribeswomen for providing their valuable time and unforgettable hospitality.

\section{AUTHORS CONTRIBUTION}

Alamgeer Khan is the primary and corresponding author of this research who has designed the entire study's concept. Intikhab Alam is the major supervisor and was responsible for designing experimental design.

Mussawar Shah was mentoring the whole research process.

Asad Ullah and Malik Muhammad Shafi have assisted the team by providing statistical expertise.

\section{REFERENCES}

1. Ahmad, K. (2007). Shortage of psychiatrists a problem in Pakistan. The Lancet, 370(9590), 817-818. https://doi.org/10.1016/S0140-6736(07)61397-X

2. Akins, H. (2017). FATA and the Frontier Crimes Regulation in Pakistan: The Enduring Legacy of British Colonialism. The Howard H. Baker Jr Center for Public Policy Brief, 5, 17. http://bakercenter.utk.edu/wpcontent/uploads/2017/11/PolicyBrief5-2017.pdf

1. Akins, H. (2018). Pakistan's' Pashtun Spring'faces off against a colonial-era law. South Asia@ LSE. http://eprints.lse.ac.uk/id/eprint/89990

2. Ali, I. (2018). Mainstreaming Pakistan's federally administered tribal areas. Special Report United States Institute of Peace. https://www.usip.org/sites/default/files/2018-03/sr-421-mainstreaming-pakistan-federallyadministered-tribal-areas.pdf

3. Ali, Z. (2014). Militancy affects everything except corruption in Fata. DAWN. Retrieved from https://www.dawn.com/news/1154019

4. Amnesty International. (2010). Pakistan: 'As If Hell Fell On Me': The Human Rights Crisis In Northwest Pakistan. Retrieved from Amnesty International Ltd Peter Benenson House 1 Easton Street London WC1X ODW United Kingdom: https://www.amnesty.org/en/documents/ASA33/004/2010/en/

5. Amnesty International. (2018). Pakistan: Historic Rights Advances for Tribal Areas and Transgender People. Amnesty International. Retrieved 24-Jan-2019 from https://www.amnesty.org/en/pressreleases/2018/05/pakistan-historic-advances-for-rights-tribal-areas-transgender-people/

6. Associated Press of Pakistan (APP). (2016). Committee Recommends Four Basic Options for Reforms in FATA, Wide Consensus on Integration of FATA with KP. Retrieved from http://www.app.com.pk/committeerecommends-four-basic-options-for-reforms-in-fata-wide-consensus-on-integration-of-fata-with-kp/

7. Aziz, S. (2017). FATA to be merged with K-P. The Express Tribune. Retrieved from https://tribune.com.pk/story/1344530/fata-merged-k-p/

8. Babbie, E. R. (2013). The basics of social research: Cengage learning.

9. Chaudhry, S. M. (2011). Introduction to statistical theory. Ilmi Kithab Khana. 
10. Christine Fair, C et al, (2009). Pakistan's war within. Survival, 51(6), 161-188. https://doi.org/10.1080/00396330903465204

11. Crawford, N. C. 2016. Update on the human costs of war for Afghanistan and Pakistan, 2001 to mid-2016. Watson Institute for International and Public Affairs, Brown University, August. Accessed at http://watson.brown.edu/costsofwar/costs/human/civilians/afghan

12. Daily Times. (2017). Tribesmen demand abolition of FCR. Retrieved from https://dailytimes.com.pk/113065/tribesmen-demand-abolition-of-fcr/

13. Das et al., (2020). Impact of conflict on maternal and child health service delivery-how and how not: a country case study of conflict affected areas of Pakistan. Conflict and health, 14, 1-16. https://doi.org/10.1186/s13031020-00271-3

14. DAWN. (2012). FCR termed 'mother of all problems in FATA'. Retrieved from https://www.dawn.com/news/770497/fcr-termed-mother-of-all-problems-in-fata

15. Democracy Reporting International. (2013). Electoral Conditions in Federally Administered Tribal Areas of Pakistan. Retrieved from Germany: https://democracy-reporting.org/dri_publications/report-electoralconditions-in-the-federally-administered-tribal-areas-of-pakistan/

16. Fabricant, M. C. (2010). War crimes and misdemeanors: Understanding zero-tolerance policing as a form of collective punishment and human rights violation. Drexel L. Rev., 3, 373. https://drexel.edu/ /media/Files/law/law\%20review/spring_2011/Fabricant.ashx?la=en

17. FATA Disaster Management Authority. (2018). Federally Administered Tribal Area (FATA). Retrieved from http://www.fdma.gov.pk/federally-administered-tribal-area-fata

18. Government of Pakistan. (2011). The Frontier Crimes Regulations (Amended in 2011). Islamabad, Pakistan Retrieved from http://www.isj.org.pk/the-frontier-crimes-regulations-amended-in-2011/

19. Hopkins, B. D. (2015). The frontier crimes regulation and frontier governmentality. The Journal of Asian Studies, 369-389. https://doi.org/10.1017/S0021911815000030

20. Hussain et al., (2016). Prevalence and distribution of human Plasmodium infection in Federally Administrative Tribal Areas of Pakistan. Acta parasitologica, 61(3), 537-543. https://doi.org/10.1515/ap-2016-0071

21. Hussain, H. (2005). FCR a bad law nobody can defend. In: Human Rights Commission of Pakistan Peshawar. http://hrcp-web.org/hrcpweb/wp-content/pdf/ff/23.pdf

22. Islam et al., (2017). People's Perception About The Powers Of Political Agent In The Federally Administered Tribal Areas (Fata): A Case Study Of Mohmand Agency. Pakistan Journal, 53(1). https://www.pscpesh.org/PDFs/PJ/Volume_53/15_Fakhr.pdf

23. Javaid, U., Haq, U., \& Akram, M. (2016). Political Challenges and Security Issues in FATA and its impact on $\begin{array}{lllll}\text { Economic Development. Stan } & \text { South }\end{array}$ http://pu.edu.pk/images/journal/csas/PDF/24\%20Umbreen\%20Javaid_v31_no1_jan-jun2016.pdf

24. Khan et al., (2019). Tick burden and tick species prevalence in small ruminants of different agencies of the Federally Administered Tribal Areas (FATA), Pakistan. International Journal of Acarology, 45(6-7), 374-380. https://doi.org/10.1080/01647954.2019.1663930

25. Khan, A. (2017). FATA as an Ungoverned Territory: A Study into Governance, Security and Terrorism. Central Asia Journal, 80. Retrieved from http://journals.uop.edu.pk/papers/04\%20Asghar\%20Khan.pdf

26. Khan, R. (2018). Legal-administrative vacuum in tribal areas. The Express Tribune. Retrieved from https://tribune.com.pk/story/1833200/6-legal-administrative-vacuum-tribal-areas/

27. Khan, S et al., (2012). The frontier crimes regulation (fcr): A socio political assessment. Central Asia issue(70), 1-14. https://doi.org/10.2139/ssrn.2765291

28. Khattak, A. R. K. (2017). Reforms to The Federally Administered Area Of Pakistan (Fata)-An Unresolved Problem. Asian Affairs, 48(3), 529-542. https://doi.org/10.1080/03068374.2017.1362872

29. Kumar, R. (2011). Research methodology: A step-by-step guide for beginners: Sage Publications Limited. https://doi.org/10.7748/nr.19.3.45.s5

30. Latif et al., (2012). Socio-political issues of Fata, a historical And contemporary perspective. Journal of Public Administration \& Governance, 2(4). https://doi.org/10.5296/jpag.v3i1.3208

31. Lutz, J. M., \& Lutz, B. J. (2010). Democracy and terrorism. Perspectives on Terrorism, 4(1), 63-74. https://www.jstor.org/stable/26298436

32. Mahmud, T. (2010). Colonial cartographies, postcolonial borders, and enduring failures of international law: The unending wars along the Afghanistan-Pakistan frontier. Brook. J. Int'l L., $36, \quad 1$. https://papers.ssrn.com/sol3/Delivery.cfm/SSRN_ID1691711_code796854.pdf?abstractid=1596835\&mirid=1\& type $=2$

33. Mahsud et al., (2016) Frontier Crimes Regulations (FCR), Status of Fundamental Human Rights in FATA and Pakistan's International Obligations. http://dx.doi.org/10.31703/gssr.2016(I-II).06

34. Naseemullah, A. (2014). Shades of sovereignty: Explaining political order and disorder in Pakistan's northwest. Studies in Comparative International Development, 49(4), 501-522. https://doi.org/10.1007/s12116014-9157-Z 
35. Naseer et al., (2017). The jirgas of PKMAP and JUI are standing in the way of FATA's much needed merger with Khyber Pakhtunkhwa. The Nation. Retrieved from https://nation.com.pk/07-Feb-2017/the-jirgas-ofpkmap-and-jui-are-standing-in-the-way-of-fata-s-much-needed-merger-with-khyber-pakhtunkhwa

36. Nazia, M. (2018). FATA needs e-health rehabilitation. The Friday Time. Retrieved from https://www.thefridaytimes.com/fata-needs-e-health-rehabilitation/

37. Office for the Coordination of Humanitarian Affairs OCHA. (2018). Pakistan: FATA Fact Sheet. Retrieved from https://www.humanitarianresponse.info/sites/www.humanitarianresponse.info/files/documents/files/kptd fact_sheet 27 aug 2018.pdf

38. Pakistan Bureau of Statistics. (2017). Province Wise Provisional Results of Census - 2017. Retrieved from https://www.pbs.gov.pk/content/block-wise-provisional-summary-results-6th-population-housing-census-2017january-03-2018

39. Rafique et al., (2017). National energy scenario of Pakistan-Current status, future alternatives, and institutional infrastructure: An overview. Renewable and Sustainable Energy Reviews, 69, 156-167. https://doi.org/10.1016/j.rser.2016.11.057

40. Rayat, C. S. (2018). Chi-Square Test ( $\chi$ 2-Test). In Statistical Methods in Medical Research (pp. 69-79): Springer. https://doi.org/10.1007/978-981-13-0827-7_9

41. Rubab, Z. (2014). De-Marginalization: a way forward to peace building in FATA. TIGAH: A Journal of Peace and Development, 77-95. https://doi.org/10.9774/GLEAF.8757.2014.ja.00007

42. Saddique et al., (2018). Potentially toxic elements in soil of the Khyber Pakhtunkhwa province and Tribal areas, Pakistan: evaluation for human and ecological risk assessment. Environmental geochemistry and health, 40(5), 2177-2190. https://doi.org/10.1007/s10653-018-0091-2

43. Sekaran, U. (2016). Research Methods For Business, A Skill Building Approach, John Willey \& Sons. Inc. New York.

44. Shah et al., (2020). Empirical Analysis of Household Food Consumption Pattern in Fata Region of Pakistan. Asian Journal of Economics, Business and Accounting, 1-8. https://doi.org/10.9734/ajeba/2020/v14i130181

45. Shah, K. (2018). Too Little, Too Late: The Mainstreaming of Pakistan's Tribal Regions. Occasional Papers. https://www.ndu.edu.pk/issra-papers/doc/ISSRA-Papers-2018-Issue-II.pdf

46. Shah, W. A. (2006). Court order on attachment of property under FCR. DAWN. Retrieved from https://www.dawn.com/news/403617

47. Shakeel et al., (2019). Achieving the end game: employing "vaccine diplomacy" to eradicate polio in Pakistan. BMC public health, 19(1), 1-8. https://doi.org/10.1186/s12889-019-6393-1

48. Shakirullah, H. (2005). FCR a bad law nobody can defend. In: Human Rights Commission of Pakistan Peshawar. http://hrcp-web.org/hrcpweb/wp-content/pdf/ff/23.pdf

49. Shaw et al .,(2012). The unbearable humanness of drone warfare in FATA, Pakistan. Antipode, 44(4), 14901509. https://doi.org/10.1111/j.1467-8330.2011.00940.x

50. Shaw, I. G. (2012). Review Essay: Life and Death in Droneworld. Critical Asian Studies, 44(4), 651-658. https://doi.org/10.1080/14672715.2012.738546

51. Shinwari, N. A. (2012). Understanding FATA: Attitudes towards Governance, Religion and Society in Pakistan's Federally Administered Tribal Areas (Volume V). http://crossasia-repository.ub.uniheidelberg.de/2715/1/Understanding_FATA_Vol_V_11.pdf

52. Shinwari, S. H. (2005). FCR a bad law nobody can defend. In: Human Rights Commission of Pakistan Peshawar. http://hrcp-web.org/hrcpweb/wp-content/pdf/ff/23.pdf

53. Spains, J. W. (1979). Pakistan's Western Borderlands: The Transformation of a Political Order: New Delhi: Vikas Publishing House. https://doi.org/10.2307/2053481

54. Tahir, M. (2015). Bombing Pakistan: How colonial legacy sustains American drones. Costs of war. https://watson.brown.edu/costsofwar/files/cow/imce/papers/2015/Tahir_FINAL\%20Costs\%20of\%20War\%206. 7.15.pdf

55. Tanguay-Renaud, F. (2009). Post-Colonial Pluralism, Human Rights \& (and) the Administration of Criminal Justice in the Federally Administered Tribal Areas of Pakistan. Sing. J. Int'l \& Comp. L., 6, 541. https://digitalcommons.osgoode.yorku.ca/cgi/viewcontent.cgi?article=3324\&context=scholarly works

56. The Express Tribune. (2015). FATA: ANP demands abolishment of FCR. The Express Tribune. Retrieved from https://tribune.com.pk/story/1017275/fata-anp-demands-abolishment-of-fcr/

57. Ullah et al., (2017). The Recent Electoral Reforms in Federally Administered Tribal Areas (FATA): An Appraisal. Journal of Political Studies, 24(2). http://www.nihcr.edu.pk/Downloads/Dr\%20Alta f\%20sb/20.\%20The\%20Recent\%20Electoral\%20Reforms\%20in\%20FATA\%20-\%20An\%20Appraisal.pdf

58. Ullah, A. (2013). Federally Administered Tribal Area (FATA) of Pakistan: Study of a Special Model of Governance. Pakistan Journal of History and Culture, 34(2), 65-94.

59. Ullah, A. (2015). Governance reforms in federally administered tribal areas (fata) of Pakistan: The past and present. Journal of Political Studies, 22(1), 215.

60. United Nations Development Programme (UNDP). (2016). Multidimensional Poverty in Pakistan. Retrieved from https://www.ophi.org.uk/wp-content/uploads/Multidimensional-Poverty-in-Pakistan.pdf 
61. Walsh, J. I., \& Piazza, J. A. (2010). Why respecting physical integrity rights reduces terrorism. Comparative Political Studies, 43(5), 551-577. https://doi.org/10.1177/0010414009356176

62. Wilson, C et al., (2019). Repression, co-optation and insurgency: Pakistan's FATA, Southern Thailand and Papua, Indonesia. Third World Quarterly, 40(4), 710-726. https://doi.org/10.1080/01436597.2018.1557012

63. Yousaf et al., (2018). Detriments of colonialism on indigenous conflict resolution: an analysis of Pakistan and Tanzania. Contemporary Justice Review, 21(4), 455-473. https://doi.org/10.1080/10282580.2018.1532795

64. Yousaf et al., (2020). Pashtun Jirga and prospects of peace and conflict resolution in Pakistan's 'tribal'frontier. Third World Quarterly, 1-18. https://doi.org/10.1080/01436597.2020.1760088

65. Yousaf, F. (2019). Pakistan's "tribal" Pashtuns, their "violent" representation, and the Pashtun Tahafuz movement. Sage Open, 9(1), 2158244019829546. https://doi.org/10.1177/2158244019829546

66. Yousaf, F. (2019). Pakistan's colonial legacy: FCR and postcolonial governance in the Pashtun tribal frontier. Interventions, 21(2), 172-187. https://doi.org/10.1080/1369801X.2018.1487322

67. Yusufzai, A. (2018). FATA-KP merger stirs hopes of peace, economic development. Pakistan Forward. Retrieved from https://pakistan.asia-news.com/en_GB/articles/cnmi_pf/features/2018/06/21/feature-01

68. Zaman et al., (2016). FATA Reforms: Community Perception and Identification Of Constraints In Implementation. Pakistan Journal of Society, Education and Language PJSEL, 2(1). Retrieved from https://www.academia.edu/download/58071313/2...2016....FATA_Reforms_Community_Perception_And_Iden tification_Of_Constraints_In_Implementation.pdf 